\title{
Impairment of heart action following various methods of surgical denervation
}

\author{
T. J. O T T O ${ }^{1}$ and P.C. CHEAH \\ The Nuffield Unit of Clinical Physiology, Department of Surgery, Royal Postgraduate Medical School, \\ Ducane Road, London, W.12
}

Surgical cardiac denervation was carried out in 25 greyhounds and their responses to exercise, propranolol, and atropine were observed between one and three months afterwards. Our experiments confirm that a denervated heart shows delayed and diminished response to exercise and no response to atropine and propranolol. We found that no cardio-circulatory mechanism seems to be present in the cavae and that hearts can be 'selectively' denervated to produce an isolated increase in right ventricular pressure which is presumably due to severance of inhibitory fibres leading to the right ventricle, so that the augmentory fibres are unopposed.

\section{DENERVATION OF THE HEART}

Transplantation of the heart, both in experimental animals and in man, results in total interruption of extrinsic innervation of the heart and may also disturb, or indeed interrupt, the conductive system of the heart. The extent of interruption of the conductive system depends mainly on the line of division of the atria, especially of the right atrium, which varies according to the technique employed.

Also other cardiosurgical operations, if connected with dissection of the venae cavae, atria, aorta, and pulmonary artery, may produce, to a varying extent, interruption of extrinsic innervation of the heart.

It has been proved that a transplanted, and thus denervated, heart changes its chemistry, metabolism, structure, and function (Willman, Merjavy, Pennell, and Hanlon, 1967b ; Cooper, Gilbert, Bloodwell, and Crout, 1961 ; Barta, Bózner, Cerný, and Mreno, 1966 ; Barta, Breuer, Pappová, and Zlatoš, 1966). Interruption of afferent and efferent innervation of the heart also produces a response from circulatory and renal systems. Elevation of systemic blood pressure results from vasoconstriction produced by stimulation of the vagus (Willman, Kaiser, Harada, Cooper, and Hanlon, 1967a). However, some influence of interruption of afferent pathways from left atrial and left ventricular baroreceptors cannot be excluded (Willman et al., 1967b).

1Present address: Warszawa 1, ul. Walowa 4m. 46, Poland.
Body fluid retention observed after transplantation which presents as cardiac failure can be explained on the basis of decreased afferent stimuli from the heart following dissection of the atria, and is not the result of impaired myocardial function (Willman et al., 1967b; Gilmore and Daggett, 1966).

The response to exercise of a transplanted heart differs from that of the normal heart. The increase in heart rate per minute is much less and the rate itself never becomes as fast as that of a healthy heart under the same strain. The return to a normal rate after exercise also takes much longer (Willman et al., 1967a ; Donald and Shepherd, 1964).

As a result of relative dissociation between the requirement of an increased output on exercise and the slow response of the heart, an initial drop in the systemic blood presusre is observed, and blood pressure never rises to the level observed in non-transplanted animals.

Although many excellent experiments have been carried out in the field of heart denervation and its disturbance following transplantation, much remains to be learned, especially regarding the influence of dissection and division of the right atrium and venae cavae.

In order to provide such data selective experiments were carried out on greyhounds, and various methods of anastomosing the right side of the heart, combined with denervation in situ, were attempted. 


\section{MATERIALS AND METHODS}

Experiments were performed on 25 greyhounds. Two pilot experiments were carried out to establish surgical technique and to test techniques of monitoring pressure. Survivals were not attempted in the pilot experiments, and the animals were afterwards sacrificed. Monitoring was achieved by inserting cannulae into: (1) the internal thoracic artery for aortic pressure; (2) the right atrium through the right atrial appendage for atrial pressure ; and (3) the right ventricle through a needle puncture for right ventricular pressure. The electrocardiogram (E.C.G.) was also recorded. Pressures and E.C.G. were monitored before and during the operations, and for 24 hours afterwards.

Before starting the actual experiments, 20 pig hearts were dissected and the atrial branch of the right coronary artery was cannulated and perfused with $0.25 \%$ methylene blue to visualize the sinus node, which was subsequently dissected. This was of great help in planning the line of division of the right atrium in later experiments on the dogs.

The dogs were divided into three groups: (1) division and resuturing of the superior vena cava (S.V.C.) and inferior vena cava (I.V.C.) in situ; (2) division and resuturing of S.V.C. and I.V.C. in situ and denervation of the heart in situ; and (3) selective denervation of the heart.

ANAESTHESIA All dogs submitted to experiments were anaesthetized. Anaesthesia was induced with thiopentone sodium (Pentothal) in $5 \%$ solution, injected intravenously in doses of $20-25 \mathrm{mg}$. $/ \mathrm{kg}$. body weight. Subsequently, dogs were intubated. Anaesthesia was maintained by 2-bromo-2-chloro $1: 1: 1$ trifluoroethane- $\mathrm{CF}_{3} \mathrm{CHClBr}$-fluothane with $0.01 \%$ w/w thymol added. A $0.75 \%$ to $2.5 \%$ concentration was used with $70 \%$ oxygen in air. Fluothane was discontinued when the chest closure was commenced. A Palmer 'Ideal' $16 / 24$ respiration pump was used to inflate the lungs throughout anaesthesia. Respiration rate was $14 /$ minute, and tidal air was adjusted to about $500 \mathrm{ml} . /$ minute.

\section{OPERATION}

Group 1 Experiments were carried out on seven dogs. Right anterolateral thoracotomy was performed through the bed of the resected 5th rib. The S.V.C. was divided and resutured without continuity of blood flow in the following manner. It was cross-clamped with two intestinal clamps, divided between them, and then anastomosed end-to-end with continuous $5 / 0$ nylon suture. Occlusion time of the S.V.C. was approximately 8 minutes.

For division and re-anastomosis of the I.V.C. with continuity of blood flow the following method was employed. A purse-string was inserted into the right atrium, which was then opened with a stab incision. A Portex PVC tube $(20 \mathrm{~mm}$. in diameter) with a large side hole was inserted into the right atrium and guided into the I.V.C., the side hole remaining free in the right atrium. Two tapes were snared around the intubated part of the I.V.C., thus enabling division and resuturing of the vein between them. During this pro- $\frac{\bar{c}}{\vec{D}}$ cedure, which took approximately 15 minutes, inferior $\stackrel{\mathbb{Q}}{\Omega}$ vena caval blood flow into the right atrium was maintained through the tube and its side hole. When 2 the anastomosis was completed the I.V.C. was ex- $\vec{O}$ tubated.

One tube was inserted into the pleural cavity, and $\vec{\omega}$ the chest was closed in layers. Monitoring lines were brought through the skin by a small stab incision in $\vec{x}$ the neck, posteriorly.

Group 2 Experiments were carried out on seven dogs. The same techniques as in group 1 were $\mathbb{E}$ employed for dividing and resuturing the S.V.C. and 을 I.V.C. and for measuring pressures. In addition to this procedure, denervation of the heart was carried out 3 in several steps as follows. The mediastinal pleura was divided at the level of the S.V.C. anastomosis. $\frac{\rho}{3}$ The pericardium was cut transversely at its attach- $\vec{\ominus}$ ment to the aorta. Subsequently, the adventitia of the aorta was divided transversely and resutured, as was. the adventitia of the lateral and anterior parts of the pulmonary artery. Connective tissue between the aorta and pulmonary artery was stripped off and visible vagal branches were divided. Pericardial attachment was dissected free around the S.V.C., I.V.C., and left $\frac{\oslash}{\varnothing}$ atrium. Following such denervation the pericardium $\triangle$ was resutured with single stitches.

When operating on one such dog (dog 525) in this 3 group, it was noticed that during denervation of the median side of the aorta a rapid increase of right ventricular pressure occurred. Denervation was discontinued at this point, and the dog was followed up (see Fig. 2). Further experiments were carried out to explain this finding and this forms the basis for such experiments in group 3.

Group 3 Experiments were performed on seven dogs. The pressures were monitored as in groups 1 and 2 , and in addition the pulmonary artery and left atrial 윽 pressures were recorded. Denervation of the heart $D$ was started by dissecting free the pericardial attachment to the S.V.C., I.V.C.. aorta, and right and left $N$ atria. Subsequently, the adventitia of the aorta was 0 cut transversely and resutured and the connective $N$ tissue between the aorta and pulmonary artery was N cleared. Such dissection was continued until a rise in right ventricular pressure was noted, after which no further denervation was performed.

POST-OPERATIVE TREATMENT The animals were nursed lying on the unoperated side. Pleural suction was maintained for 24 hours, when both monitoring lines and intercostal tube were removed.

MORTALITY The overall mortality was eight. Two were from group 1. One dog died six hours after surgery, due to bleeding from the I.V.C. anastomosis. 
The other one died on the 6th post-operative day from a large pulmonary embolus. Three were from group 2 and three from group 3. All these dogs died within 6 to 30 hours following surgery.

Their condition seemed to be very satisfactory and they died suddenly with symptoms of cardiac arrest. No evident clinical reason for death was noted. Necropsy did not reveal any abnormalities. It appeared that death was due to the decreased ability of the denervated heart to adapt itself to surgical stress, or stress produced by the transportation of the animals when they were moved to the operating room for recording pressures 24 hours after surgery.

FUNCTIONAL TESTS All animals which survived the operations were submitted to functional tests between one and three months following the initial procedure. The right external carotid artery and the right jugular vein were exposed and catheters were introduced into the right atrium, right ventricle, and carotid artery for pressure measurements. One or two days later, E.C.G., right atrial, right ventricular, and systemic pressures were recorded, and the animals were submitted to exertion until severe exhaustion occurred. The pressures and E.C.G. were monitored until they recovered. After a few hours' rest, the animals were given propranolol, $2 \mathrm{mg}$. $/ \mathrm{kg}$. body weight, and the tests were repeated. After conclusion of the experiments atropine was injected in increasing doses and all parameters were monitored again.
Two healthy dogs, treated as controls, were also submitted to the above described tests.

\section{RESUL,TS}

GROUP 1 (Fig. 1 and Table I). No change in E.C.G., pulse rate or pressures was observed which could be attributed to division of the cavae. No evidence was found of any receptors lying within these vessels and regulating the heart action or influencing, in any way, the circulatory system. All animals from this group, when submitted to functional tests, behaved like healthy dogs. Also, their response to propranolol and atropine was normal.

The only change following the resuturing of the venae cavae was a slight drop in right heart pressures observed in some animals and resulting from a narrowing of the vessel at the site of anastomosis. Differences in heart rate were not significant and were due to different depths of anaesthesia or sedation.

Dogs responded to exercise with a normal increase in heart rate (average increase from 100/ minute to 180 /minute) and subsequent increase in blood pressure from an average of $120 / 90 \mathrm{~mm} . \mathrm{Hg}$ to $160 / 110 \mathrm{~mm}$. $\mathrm{Hg}$. Ten minutes after exercise these parameters returned to normal.
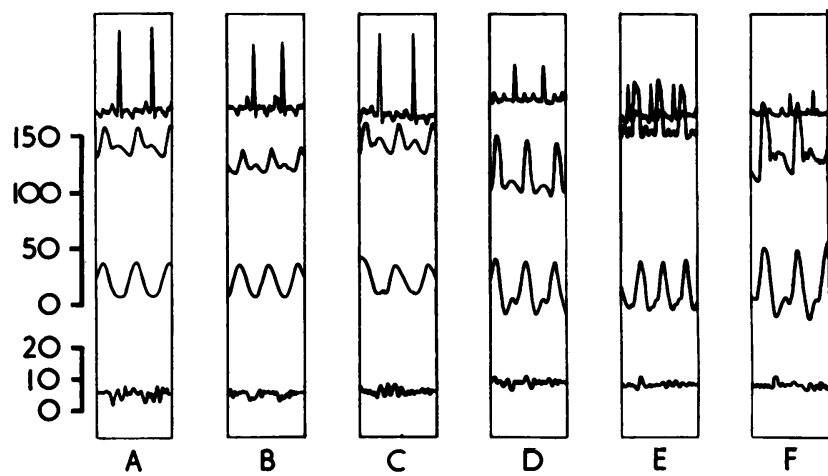

FIG. 1. Dog 689. Division and resuturing of S.V.C. and I.V.C. (A) Before the division of cavae. Heart rate 160/min. Systemic pressure $150 / 130 \mathrm{~mm}$. Hg. Right ventricular pressure $30 / 0 \mathrm{~mm}$. Hg. Right atrial pressure $8 / 0 \mathrm{~mm}$. Hg. (B) During occlusion of cavae. Decrease of systemic pressure. Slight increase of heart rate. $(C)$ After anastomosing cavae. Return to initial rate and systemic pressure. (D) Three months after operation. Slightly lower systemic pressure and diastolic right ventricular pressure probably resulting from mild stenosis of I.V.C. anastomosis. (E) Normal response to exercise-increase of systemic pressure to $190 / 140 \mathrm{~mm}$. $\mathrm{Hg}$ and increase of heart rate. (Systemic pressure recording overlaps E.C.G. recording.) (F) Five minutes after exercise. Return to normal rate. Systemic pressure still slightly elevated. 
T A B L E I

GROUP 1. DIVISION AND RESUTURING OF S.V.C. AND I.V.C. (Average results in 7 dogs)

\begin{tabular}{|c|c|c|c|c|c|c|}
\hline $\begin{array}{l}\text { No. of dogs, } 7 \\
\text { Submitted to } \\
\text { functional tests, } 5\end{array}$ & E.C.G. & $\begin{array}{l}\text { Heart Rate } \\
\text { per min. }\end{array}$ & $\begin{array}{c}\text { Right Arterial } \\
\text { Pressure } \\
\text { (mm. Hg) }\end{array}$ & $\begin{array}{c}\text { Right } \\
\text { Ventricular } \\
\text { Pressure } \\
\text { (mm. Hg) }\end{array}$ & $\begin{array}{l}\text { Systemic } \\
\text { Pressure } \\
(\mathbf{m m} . \mathbf{H g})\end{array}$ & Remarks \\
\hline $\begin{array}{l}\text { Before division } \\
\text { After division }\end{array}$ & $\begin{array}{l}\text { Normal } \\
\text {," }\end{array}$ & $\begin{array}{l}110+10 \\
115 \pm 8\end{array}$ & $\begin{array}{l}6.5 / 2 \cdot 5 \\
5.0 / 2 \cdot 0\end{array}$ & $\begin{array}{l}30 / 5 \\
25 / 5\end{array}$ & $\begin{array}{l}125 / 100 \\
120 / 95\end{array}$ & No significant change \\
\hline $\begin{array}{l}\text { Before exercise } \\
\text { On exercise } \\
10 \text { min. rest }\end{array}$ & ,", & $\begin{array}{l}100 \pm 8 \\
180 \pm 12 \\
120 \pm 10\end{array}$ & $\begin{array}{l}5 \cdot 5 / 2 \cdot 5 \\
6 \cdot 0 / 2 \cdot 5 \\
6 \cdot 5 / 2 \cdot 0\end{array}$ & $\begin{array}{l}25 / 0 \\
35 / 5 \\
30 / 0\end{array}$ & $\begin{array}{l}120 / 90 \\
160 / 110 \\
115 / 90\end{array}$ & Normal response \\
\hline $\begin{array}{l}\text { After propranolol } \\
\text { On exercise } \\
10 \text { min. rest }\end{array}$ & ,", & $\begin{array}{c}95 \pm 10 \\
140 \pm 2 \\
80 \pm 8\end{array}$ & $\begin{array}{l}5 \cdot 5 / 2 \cdot 0 \\
6 \cdot 5 / 2 \cdot 0 \\
5 \cdot 0 / 2 \cdot 0\end{array}$ & $\begin{array}{l}25 / 0 \\
35 / 5 \\
25 / 0\end{array}$ & $\begin{array}{l}120 / 90 \\
140 / 100 \\
115 / 85\end{array}$ & Expected response \\
\hline After atropine & ," & $180 \pm 10$ & $6 \cdot 5 / 2 \cdot 5$ & $30 / 0$ & $125 / 90$ & Expected response \\
\hline
\end{tabular}

Following injection of propranolol there was some slowing of pulse rate, and the increase in heart rate on exercise was much less than without propranolol. Also, the increase in systemic blood pressure was less. These changes in response were expected as propranolol, being a $\beta$-adrenergicreceptor blocking agent, deprives the heart and circulatory system of the accelerating action of catecholamines.

Following injection of atropine, there was a marked increase of heart rate to $180 /$ minute This is again to be expected as atropine is a vagal blocker.

GROUP 2 (Table II) Dogs in this group responded to denervation by an increase of systemic blood pressure. The increase, though significant, was not very high but was observed in all animals (average increase from $130 / 105 \mathrm{~mm}$. $\mathrm{Hg}$ to $155 / 120 \mathrm{~mm}$. $\mathbf{H g}$ ). Following the increase in systemic pressure a slight increase in right ventricular pressure was also noted. This increase, however, was clearly secondary, except in one animal (dog 525) which will be discussed separately. Other parameters remained virtually unchanged. The response of denervated dogs to exercise was quite different from that of healthy animals or from those who had only division and anastomosis of the venae cavae. Their response to propranolol and atropine was also abnormal.

On exercise, the increase in heart rate was delayed and never reached the level observed in non-denervated animals (average increase from $100 /$ minute to $120 /$ minute). It took much longer for the heart rate to settle down following exertion, and 30 minutes elapsed before the rate returned to its pre-exercise level. In some animals there was an initial drop in the blood pressure on exercise $(150 / 120 \mathrm{~mm}$. $\mathrm{Hg}$ to $140 / 110 \mathrm{~mm}$. $\mathrm{Hg})$ and subsequently the increase was much less than in the undenervated dogs.

Following the injection of propranolol, there was slowing of the heart rate from $100 \pm 10 /$ minute to $80 \pm 9 /$ minute and the animals were hardly able to stand the exertion test. There was no increase of blood pressure or heart rate on exertion following the injection of propranolol.

Denervated animals did not respond to atropine at all.

T A B L E I I

GROUP 2. DIVISION AND ANASTOMOSIS OF S.V.C. AND I.V.C. PLUS DENERVATION (Average results in 6 dogs)

\begin{tabular}{|c|c|c|c|c|c|c|}
\hline $\begin{array}{l}\text { No. of dogs, } 6 \\
\text { Submitted to } \\
\text { functional tests, } 3\end{array}$ & E.C.G. & $\begin{array}{l}\text { Heart Rate } \\
\text { per min. }\end{array}$ & $\begin{array}{l}\text { Right Arterial } \\
\text { Pressure } \\
\text { (mm. Hg) }\end{array}$ & $\begin{array}{c}\text { Right Ventricular } \\
\text { Pressure } \\
\text { (mm. Hg) }\end{array}$ & $\begin{array}{l}\text { Systemic } \\
\text { Pressure }\end{array}$ & Remarks \\
\hline $\begin{array}{l}\text { Before operation } \\
\text { After operation }\end{array}$ & $\begin{array}{c}\text { Normal } \\
,,\end{array}$ & $\begin{array}{l}105 \pm 8 \\
105 \pm 12\end{array}$ & $\begin{array}{l}6 \cdot 5 / 2 \cdot 5 \\
7 \cdot 0 / 2 \cdot 5\end{array}$ & $\begin{array}{l}25 / 0 \\
30 / 5\end{array}$ & $\begin{array}{l}130 / 105 \\
155 / 120\end{array}$ & $\begin{array}{l}\text { Significant increase } \\
\text { in blood pressure }\end{array}$ \\
\hline $\begin{array}{l}\text { Before exercise } \\
\text { On exercise } \\
10 \mathrm{~min} \text {. after } \\
30 \mathrm{~min} \text {. after }\end{array}$ & $\begin{array}{l}\text {," } \\
\text {,", }\end{array}$ & $\begin{array}{l}100 \pm 10 \\
102 \pm 8 \\
120 \pm 10 \\
102 \pm 12\end{array}$ & $\begin{array}{l}6 \cdot 0 / 2 \cdot 0 \\
6 \cdot 5 / 2 \cdot 5 \\
6 \cdot 0 / 2 \cdot 5 \\
6 \cdot 0 / 2 \cdot 5\end{array}$ & $\begin{array}{l}25 / 0 \\
25 / 0 \\
25 / 0 \\
25 / 0\end{array}$ & $\begin{array}{l}150 / 120 \\
140 / 110 \\
155 / 120 \\
145 / 110\end{array}$ & $\begin{array}{l}\text { Initial decrease in } \\
\text { blood pressure } \\
\text { Delayed response } \\
\text { to exercise }\end{array}$ \\
\hline $\begin{array}{l}\text { After propranoiol } \\
\text { On exercise }\end{array}$ & $\begin{array}{l}\text { Occ. 2nd } \\
\text { degree block } \\
\text { Normal }\end{array}$ & $\begin{array}{l}80 \pm 9 \\
80 \pm 10\end{array}$ & $\begin{array}{l}6 \cdot 0 / 2 \cdot 0 \\
6 \cdot 0 / 2 \cdot 0\end{array}$ & $\begin{array}{l}20 / 0 \\
25 / 0\end{array}$ & $\begin{array}{l}150 / 110 \\
140 / 105\end{array}$ & $\begin{array}{l}\text { Bradycardia } \\
\text { No increase of heart } \\
\text { rate on exercise }\end{array}$ \\
\hline $\begin{array}{l}10 \mathrm{~min} . \text { rest } \\
30 \text { min. rest }\end{array}$ & ,", & $\begin{array}{l}80 \pm 10 \\
80 \pm 10\end{array}$ & $\begin{array}{l}6 \cdot 0 / 2 \cdot 0 \\
6 \cdot 0 / 2 \cdot 0\end{array}$ & $\begin{array}{l}25 / 0 \\
25 / 0\end{array}$ & $\begin{array}{l}140 / 100 \\
130 / 100\end{array}$ & $\begin{array}{l}\text { Increasing brady- } \\
\text { cardia on rest }\end{array}$ \\
\hline After atropine & ", & $100 \pm 19$ & $6 \cdot 5 / 2 \cdot 5$ & $25 / 0$ & $150 / 120$ & No response \\
\hline
\end{tabular}



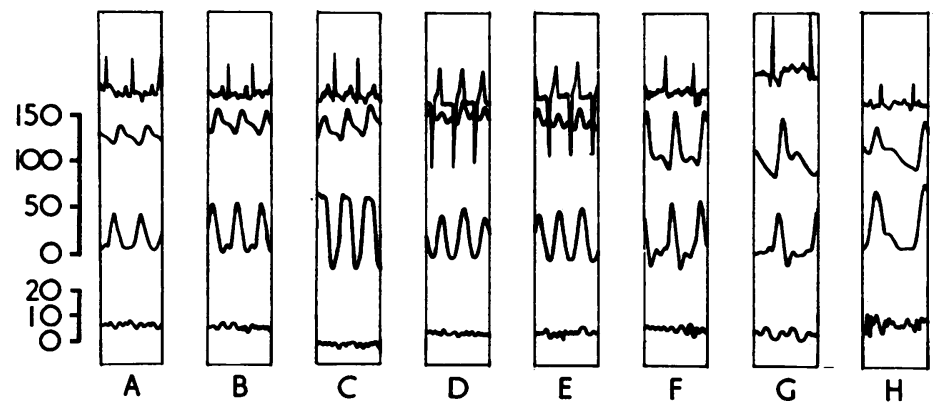

FIG. 2. Dog 525. Division and resuturing of S.V.C. and I.V.C. and denervation of heart. (A) Before division of cavae and denervation. Systemic pressure 140/120 mm. Hg. Right ventricular pressure $40 / 2 \mathrm{~mm}$. Hg. Right atrial pressure $7 \mathrm{~mm}$. Hg. Heart rate 170/minute. (B) Following division and resuturing of venae cavae and during denervation. Rise of systemic pressure to $150 / 120 \mathrm{~mm}$. Hg. Significant rise in right ventricular pressure $60 / 0$ $\mathrm{mm}$. Hg. (C) After denervation. Right ventricular pressure $70 /-5 \mathrm{~mm}$. $\mathrm{Hg}$. Right atrial pressure $2 \mathrm{~mm}$. Hg. Other parameters unchanged. (D) Six weeks later. Systemic pressure 150/-30 mm. Hg. Right ventricular pressure lower than directly after denervation but still higher than initial. (E) On exercise-slight decrease of systemic pressure; right ventricular pressure, right atrial pressure, and heart rate unchanged. (F) Five minutes after exercise, no increase in heart rate or systemic pressure. (G) Decrease in systemic pressure and heart rate following propranolol. (H) Further slight decrease in systemic pressure and heart rate following exercise after propranolol.
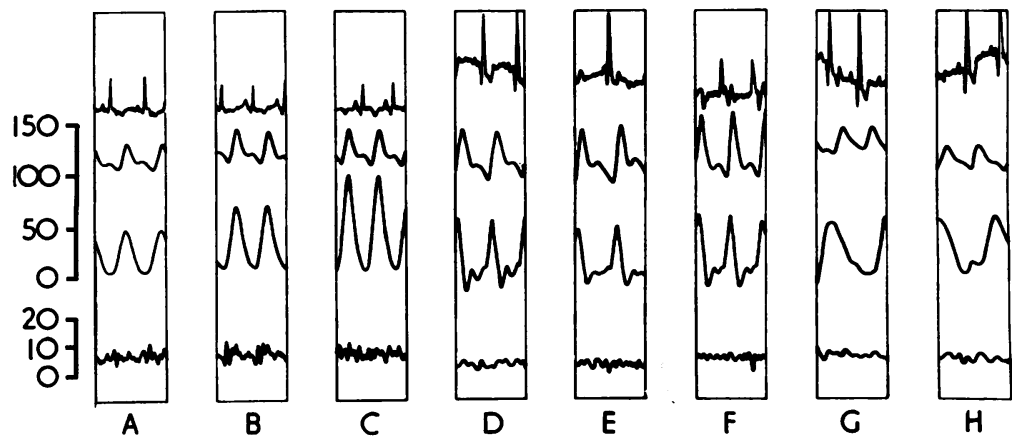

FIG. 3. Dog 948. Selective denervation of heart. (A) Before denervation. Heart rate 120/minute. B.P. 130/105 mm. Hg. Right ventricular pressure $45 / 0 \mathrm{~mm}$. $\mathrm{Hg}$. (B) After denervation. Heart rate 125/minute. Slight increase in systemic pressure. Right ventricular pressure $65 / 0 \mathrm{~mm}$. $\mathrm{Hg}$. (C) Five minutes after denervation. No change in rate or systemic pressure. Right ventricular pressure increased to 90/0 $\mathrm{mm}$. Hg. (D) One month later. Right ventricular pressure still much higher than initial before denervation-60/-10 mm. $\mathrm{Hg}$. (E) On exercise no increase in rate or systemic pressure. (F) Slight increase in rate and systemic pressure 5 minutes following exercise. (G) Decrease in systemic pressure following propranolol. (H) Further slight decrease in systemic pressure and slight decrease in rate on exercise after propranolol.

In dog 525 (Fig. 2), five minutes after denervation the right ventricular pressure reached $70 / 0$ $5 \mathrm{~mm}$. $\mathrm{Hg}$ from the previous level of $40 / 2 \mathrm{~mm}$. $\mathrm{Hg}$ and stayed at this level for the next 24 hours, during which time pressures were monitored. Systemic pressure rose from $140 / 120$ to $150 / 130$, other parameters did not change. Six weeks later the dog was catheterized again. At this time the right ventricular pressure was still higher than the initial pressure. There was no increase in heart rate on or following exertion, and a slight drop in systemic pressure was noticed on exertion. 
T A B L E I I I

GROUP 3. SELECTIVE DENERVATION OF THE HEART (Average results in 5 dogs)

\begin{tabular}{|c|c|c|c|c|c|c|}
\hline $\begin{array}{l}\text { No. of dogs, } 5 \\
\text { Submitted to } \\
\text { functional tests, } 5\end{array}$ & E.C.G. & $\begin{array}{c}\text { Heart Rate } \\
\text { per min. }\end{array}$ & $\begin{array}{c}\text { Right Arterial } \\
\text { Pressure } \\
\text { (mm. Hg) }\end{array}$ & $\begin{array}{c}\text { Right Ventricular } \\
\text { Pressure } \\
\text { (mm. Hg) }\end{array}$ & $\begin{array}{l}\text { Systemic } \\
\text { Pressure }\end{array}$ & Remarks \\
\hline $\begin{array}{l}\text { Before operation } \\
\text { After operation }\end{array}$ & $\begin{array}{c}\text { Normal } \\
\text {, }\end{array}$ & $\begin{array}{l}100 \pm 6 \\
102 \pm 7\end{array}$ & $\begin{array}{l}5 \cdot 5 / 2 \cdot 5 \\
5 \cdot 5 / 2 \cdot 0\end{array}$ & $\begin{array}{l}25 / 0 \\
55 / 0\end{array}$ & $\begin{array}{l}125 / 100 \\
135 / 110\end{array}$ & $\begin{array}{l}\text { Significant increase } \\
\text { in right ventri- } \\
\text { cular pressure }\end{array}$ \\
\hline $\begin{array}{l}\text { Before exercise } \\
\text { On exercise } \\
10 \text { min. rest } \\
30 \text { min. rest }\end{array}$ & $\begin{array}{l},, \\
,,\end{array}$ & $\begin{array}{r}90 \pm 8 \\
105 \pm 8 \\
100 \pm 7 \\
80 \pm 6\end{array}$ & $\begin{array}{l}5 \cdot 5 / 2 \cdot 5 \\
5 \cdot 0 / 2 \cdot 0 \\
6 \cdot 0 / 2 \cdot 5 \\
5 \cdot 0 / 2 \cdot 0\end{array}$ & $\begin{array}{l}35 / 0 \\
35 / 0 \\
30 / 0 \\
35 / 0\end{array}$ & $\begin{array}{l}130 / 110 \\
140 / 110 \\
135 / 105 \\
130 / 110\end{array}$ & $\begin{array}{l}\text { Slight increase in } \\
\text { rate and blood } \\
\text { pressure }\end{array}$ \\
\hline $\begin{array}{l}\text { After propranolol } \\
\text { On exercise } \\
10 \text { min. rest } \\
30 \text { min. rest }\end{array}$ & $\begin{array}{l}\text {, } \\
,, \\
,,\end{array}$ & $\begin{array}{l}80 \pm 6 \\
80 \pm 6 \\
70 \pm 8 \\
70 \pm 8\end{array}$ & $\begin{array}{l}6 \cdot 0 / 2 \cdot 5 \\
5 \cdot 5 / 2 \cdot 5 \\
6 \cdot 0 / 2 \cdot 5 \\
6 \cdot 0 / 2 \cdot 5\end{array}$ & $\begin{array}{l}35 / 0 \\
30 / 0 \\
30 / 0 \\
30 / 0\end{array}$ & $\begin{array}{l}120 / 95 \\
115 / 90 \\
120 / 100 \\
125 / 100\end{array}$ & $\begin{array}{l}\text { No significant } \\
\text { change }\end{array}$ \\
\hline After atropine & , , & $100 \pm 12$ & $5 \cdot 5 / 2 \cdot 0$ & $35 / 0$ & $130 / 105$ & $\begin{array}{l}\text { Variable increase in } \\
\text { rate }\end{array}$ \\
\hline
\end{tabular}

There was a slowing down of heart rate and a decrease in systemic pressure following propranolol, which was more marked on exertion.

It was assumed that partial denervation of the heart producing a disturbance in systemic-vagal balance was responsible for this phenomenon.

GROUP 3 (Fig. 3 and Table III) In this group, denervation of the aorta was carried out only to the point when an increase in right ventricular pressure was observed. In three animals, however, dissection around the aorta did not produce the phenomenon of isolated increase of right ventricular pressure. Very slight increase in systemic pressure occurred in some animals as well (on the average from $125 / 100 \mathrm{~mm}$. $\mathrm{Hg}$ to $135 / 110 \mathrm{~mm}$. $\mathrm{Hg}$ ), but the degree of increase was in no way comparable with the increase of right ventricular pressure, which averaged from $25 / 0 \mathrm{~mm}$. $\mathrm{Hg}$ before operation to $55 / 0 \mathrm{~mm}$. $\mathrm{Hg}$ after denervation and then stayed at the highest achieved level for 24 hours, during which time pressures were monitored. Heart rate and left atrial and right atrial pressures remained virtually unchanged.

Animals which responded to such denervation by an increase in right ventricular pressure, when catheterized 4 to 8 weeks later, showed a right ventricular pressure of $35 / 0 \mathrm{~mm}$. $\mathrm{Hg}$ on the average. This is still higher than the initial values but not quite so high as during the first 24 hours following denervation.

The response to exercise was delayed and limited but not quite so much as in animals in group 2. Exercise produced an increase in heart rate (on the average from $90 /$ minute to 105 / minute) and blood pressure (from $130 / 110 \mathrm{~mm}$. $\mathrm{Hg}$ to $140 / 110 \mathrm{~mm}$. $\mathrm{Hg}$ ). There was no change in right ventricular and right atrial pressures on exercise. After exercise it took about 30 minutes before the blood pressure and heart rate returned to their pre-exercise level.

The response to propranolol was identical to $\stackrel{\widehat{\supset}}{\supset}$ that in group 2. After injection of propranolol the $\vec{\theta}$ heart rate slowed and a slight decrease of systemic blood pressure occurred. On exercise there was no increase in heart and blood pressure. The response to atropine varied; two animals responded to the dose of 4-5 mg. by an increase in heart rate of 25 and 20 beats/minute, respectively. One responded to the dose of $6 \mathrm{mg}$. by an increase of 15 beats/ minute, and one did not respond to the atropine injection.

The three dogs which did not respond to denervation by an increase in right ventricular pressure behaved, in all respects, as the dogs from group 2. It was assumed that they were 'totally' denervated in situ and parameters obtained from these dogs were not included in Table III.

\section{DISCUSSION}

Suggestions have been made that specific baro- $\frac{\text { 일 }}{2}$ receptors are located in the venae cavae, which $\frac{D}{O}$ may influence heart dynamics. No proof of the existence of such receptors was found during the $N$ presented experiments. The dogs which were submitted to division and resuturing of the venae ${ }_{N}$ cavae did not show any change in heart action, $\omega$ dynamics or pressures which would confirm the existence of any regulating mechanism located $\stackrel{\circ}{\varnothing}$ within the venae cavae. When investigated between $\mathbb{\Phi}$ one and three months later, they responded to ? exercise, atropine, and propranolol in the same $\frac{0}{B}$ manner as healthy animals. It has to be stressed $\underset{\mathbb{D}}{\stackrel{O}{(}}$ that the period of time which elapsed between $\stackrel{\odot}{\square}$ surgery and functional tests was too short to allow $\mathbb{\perp}$ for regeneration of any extrinsic innervation $\overline{0}$ (Willman, Cooper, and Hanlon, 1964). 
Changes in heart function, such as different patterns of response to exercise, propranolol, and atropine following denervation of the heart, have been reported before (Willman et al., 1967b; Cooper et al., 1961 ; Willman et al., 1967a ; Stone, Bishop, and Dong, 1967 ; Donald, Ferguson, and Milburn, 1968). Our experiments confirm that a heart denervated in situ shows delayed and diminished response to exercise (Willman et al., 1967a), does not respond to atropine (Stone et al., 1967), and that beta-adrenergic blockade further reduces its ability to respond and adapt itself to strain (Stone et al., 1967 ; Donald et al., 1968).

Since these studies were completed, evidence has become available from D. A. Cooley and his colleagues (1969) that man responds in a similar manner to total cardiac denervation. Follow-up studies of 9 of their 17 patients subsequent to cardiac transplantation have shown their delayed response to stress. It would appear, however, that this, in itself, is not a serious drawback, and that, in the absence of rejection, cardiac performance has been satisfactory.

Eight dogs in these experiments (1 from group 2 and 7 from group 3) were submitted to what we would like to call 'selective denervation' of the heart. We use the term 'selective' in the sense that dissection of the adventitia of the aorta and the connective tissue between the aorta and pulmonary artery was only carried to the point when the right ventricular pressure was suddenly and significantly raised. Following this phenomenon, no further attempt at denervation was made. It was successful in five animals. Selectively denervated animals responded by increasing the right ventricular systolic pressure, whereas other monitored parameters remained relatively unchanged. When investigated between one and three months later they still showed right ventricular pressure higher than the initial pressure.

It has been proved that stimulation of the stellate ganglion, its ansal connexions to the caudal cervical ganglion, and individual cardiac nerves passing to the cardiac plexus produces gross inotropic and chronotropic changes in cardiac activity (Szentivanyi, Pace, Wechsler, and Randall, 1967 ; Randall, Szentivanyi, Pace, Wechsler, and Kaye, 1968a). Electrical stimulation of these structures produced augmentation in the force of contraction of both ventricles amounting in their basal segments to $100 \%$ (Randall et al., 1968a ; Osadjan and Randall, 1964).

Pace, Randall, Wechsler, and Priola (1968) have proved that, following sympathetic blockade, right and left vagal stimulation induced elevation in the right ventricular systolic pressure and end diastolic pressure.

Cardiac sympathetic and parasympathetic fibres appear to be intermingled and the presence of adrenergic (presumably sympathetic) and cholinergic fibres descending to the ventricles have recently been demonstrated in the vagosympathetic trunk (Randall, Wechsler, Pace, and Szentivanyi, 1968b). A considerable variation in the distribution of fibres from the left sympathetic trunk to the right heart and from the right sympathetic trunk to the left side of the heart has also been shown (Randall et al., 1968a). However, the normal pattern is that large sympathetic nerves reach the base of the heart anteriorly and descend on either side of the main pulmonary artery. Nerves descending on the right of the pulmonary artery go to the atria and right ventricle.

When denervating the hearts 'selectively' we cut the adventitia of the aorta and connective tissue between the aorta and the pulmonary artery. Usually at that time an increase in right ventricular pressure occurred. We presume that inhibitory fibres leading to the right ventricle were at that time severed, which elicited the action of augmentory fibres. This increased the contractile force of the right ventricle, resulting in increased right ventricular pressure. The response in contractile force of the right ventricle might have been additionally enhanced by previous denervation of the right atrium, produced when pericardial attachments to cavae and the right atrium were dissected. This probably severed afferent innervation, which may to some extent regulate right heart pressures.

The fact that in some experiments there was no increase in right ventricular pressure can be explained by variations in the pattern of innervation of the heart, which in dogs is quite common.

It is conceivable that a similar pattern of isolated cardiac response may be induced during dissection around the roots of the great vessels in some cardio-surgical operations in man. Proof of this, however, would be obtained only if cardiac catheterization were undertaken routinely in postoperative cardiac patients, an unjustifiable precedent. Nevertheless, this mechanism may account for an occasional anomalous response to operation.

This work was supported by a grant from the British Heart Foundation.

The authors have pleasure in expressing their gratitude to Professor D. G. Melrose for his valuable guidance and encouragement of this work. We also wish to thank Mrs. J. Becket, Mr. E. Williams, and Mr. S. Adams for their excellent technical assistance. 


\section{REFERENCES}

Barta, E., Bózner, A., Černý. J., and Mreno, E. (1966). Influence of complete surgical denervation of the heart on the structural integrity of the heart muscle. Exp. Med. Surg., 24, 228.

- Breuer, E., Pappová, E., and Zlatoš, L. (1966). Influence of surgical denervation of the heart on the energetic metabolism and cardiac efficiency. Ibid., 24, 319 .

Cooley. D. A., Bloodwell, R. D., Hellman, G. L., Leachman, R. D., Nova, J. J. and Milan, J. D. (1969). Cardiac transplantation. General considerations and results. Ann. Surg., 169, 892.

Cooper, T., Gilbert, J. W., Bloodwell, R. P., and Crout, J. R. (1961). Chronic extrinsic cardiac denervation by regional neural ablation. Circulat. Res., 9, 275.

Donald, D. E., Ferguson, D. A., and Milburn, S. E. (1968). Effect of beta-adrenergic receptor blockade on racing performance of greyhounds with normal and with denervated hearts. Ibid., 22, 127.

— and Shepherd, J. T. (1964). Initial cardiovascular adjustment to exercise in dogs with chronic cardiac denervation. Amer. J. Physiol., 207, 1325

Gilmore, J. P., and Daggett, W. M. (1966). Response of the chronic cardiac denervated dog to acute volume expansion. Ibid., 210, 509 .

Osadjan, C. E., and Randall, W. C. (1964). Effects of left stellate ganglion stimulation on left ventricular synchrony in dogs. Ibid., 207,181 .
Pace, J. B., Randall, W. C., Wechsler, J. S., and Priola, D. V. (1968). Alterations in ventricular dynamics induced by stimulation of the cervical vagosympathetic trunk. Ibid., 214, 1213.

Randall, W. C., Szentivanyi, M., Pace, J. B., Wechsler, J. S., and Kaye, M. P. (1968a). Patterns of sympathetic nerve projections onto the canine heart. Circulat. Res., 22, 315.

- Wechsler, J. S., Pace, J. B., and Szentivanyi, M. (1968b). Alterations in myocardial contractility during stimulation of the cardiac nerves. Amer. J. Physiol., 214, 1205.

Stone, H. L., Bishop, V. S., and Dong, E. (1967). Ventricular function in cardiac-denervated and cardiac-sympathectomized conscious dogs. Circulat. Res., $20,587$.

Szentivanyi, M., Pace, J. B., Wechsler, J. S., and Randall, W. C. (1967). Localized myocardial responses to stimulation of cardiac sympathetic nerves. Ibid., 21, 691 .

Willman, V. L., Cooper, T., and Hanlon, C. R. (1964). Return of neural responses after autotransplantation of the heart. Amer. J. Physiol., 207, 187.

- Kaiser, G. C., Harada, Y., Cooper, T., and Hanlon, C. R (1967a). Physiologic alteration following transplantation of the heart. Advances in Transplantation, pp. 661-665.

_- Merjavy, J. P., Pennell, R., and Hanlon, C. R. (1967b). Response of the autotransplanted heart to blood volume expansion. Ann. Surg., 166, 513. 